\title{
Prevention of Pregnancy Complications in Antiphospholipid Syndrome
}

\author{
Andreas Czwalinna ${ }^{1}$ Frauke Bergmann ${ }^{1}$ \\ 1 amedes MVZ wagnerstibbe für Laboratoriumsmedizin, Hämostaseologie, \\ Humangenetik und Mikrobiologie, Hannover, Germany \\ Address for correspondence Dr. med. Frauke Bergmann, amedes \\ MVZ wagnerstibbe, Georgstr. 50, 30159 Hannover, Germany \\ (e-mail: frauke.bergmann@amedes-group.com). \\ Hämostaseologie 2020;40:174-183.
}

\begin{abstract}
Keywords

- antiphospholipid syndrome

- antiphospholipid antibodies

- aPL profile

- adverse pregnancy outcome

- recurrent fetal loss

\section{Zusammenfassung}

Schlüsselwörter

- Antiphospholipidsyndrom

- Antiphospholipidantikörper

- aPL-Profil

- Schwangerschaftskomplikationen

- Wiederholte Spontanaborte (WSA)

Despite a lot of research on antiphospholipid antibodies (aPL), standardization of test systems, and better definition of its clinical symptoms, the pathomechanism of this acquired autoimmune disease is not yet fully explained. Progress in treatment increased the live birth rate in 70 to $80 \%$ of women suffering from obstetric antiphospholipid syndrome (OAPS). However, still 20 to $30 \%$ will develop adverse pregnancy outcome. Lack of awareness of this disorder as the cause for pregnancy complications is very harmful to mothers and to their newborns. Complications can be avoided or minimized by proper treatment. The aim of this article is to increase the awareness of gynecologists and medical personal for OAPS.

Trotz erheblicher Forschungsaktivität auf dem Gebiet Antiphospholipid-Antikörper (aPL) über drei Dekaden, verbesserter Standardisierung der Testsysteme und exakter Klassifikation der klinischen Kriterien als Basis aktueller Studien, ist der Pathomechanismus dieser erworbenen Autoimmunerkrankung noch nicht völlig aufgeklärt. Durch Fortschritte in der Behandlung betroffener Frauen ist die Lebendgeburtenrate bei Frauen mit gynäkologischem (obstetrical) Antiphospholipid-Syndrom (OAPS) auf 70-80\% gestiegen. Trotzdem treten in 20-30\% der Schwangerschaften schwere Schwangerschaftskomplikationen auf. Das fehlende Wissen um dieses Krankheitsbild als Ursache von Schwangerschaftskomplikationen bzw. das Nichterkennen der Symptome ist für betroffene Frauen und ihr Neugeborenes gefährlich. Komplikationen wären durch Prophylaxemaßnahmen vermeidbar bzw. zu reduzieren. Ziel dieser Übersichtsarbeit ist es, das Wissen um diese Erkrankung bei Gynäkologen und medizinischem Fachpersonal zu vertiefen und die Aufmerksamkeit für dieses Krankheitsbild zu schärfen.
\end{abstract}

\section{Introduction}

Antiphospholipid syndrome (APS) is an acquired autoimmune disease and a severe prothrombotic condition. It is defined by the combination of clinical symptoms and persistent detection of antiphospholipid antibodies (aPL) in the patient as listed in the so-called Sydney classification. ${ }^{1}$

\section{Clinical Criteria of APS as Defined by Sydney Classification}

\section{Pregnancy Morbidity}

- $\geq 1$ unexplained death of a morphologically normal fetus $\geq 10$ weeks of gestation.

(c) 2020 Georg Thieme Verlag KG Stuttgart · New York
DOI https://doi.org/

10.1055/a-1113-0689

ISSN 0720-9355

accepted

January 23, 2020 
- $\geq 1$ premature delivery of a morphologically normal fetus $<34$ weeks gestation because of severe preeclampsia (PE) or eclampsia (defined according to standard definitions) or recognized features of placental insufficiency.

- $\geq 3$ unexplained consecutive miscarriages at $<10$ weeks of gestation, with maternal and paternal factors (such as anatomical, hormonal, or chromosomal abnormalities) excluded.

\section{Vascular Thrombosis}

- $\geq 1$ clinical episode of arterial, venous, or small-vessel thrombosis.

- Thrombosis must be objectively confirmed.

- If histopathological confirmation is used, thrombosis must be present without inflammation of the vessel wall.

The classification criteria have changed over the years and are currently again under revision.

The term aPL is not quite correct because those antibodies in APS comprise a heterogeneous group targeting phospholipids, phospholipid-protein complexes, and phospholipidbinding proteins. Beta2-glygoprotein I ( $\beta 2$-GPI) is the main antigen in this autoimmune condition. ${ }^{2}$ This protein has several functions including the regulation of coagulation and complement cascade. The recognition is a milestone in understanding APS and has implications on current as well as on further treatment options for those patients.

Laboratory features are the detection of lupus anticoagulant (LA, coagulation assays) and/or anti-cardiolipin (aCL)and/or anti-B2-GPI antibodies of isotype immunoglobulin G (IgG) and/or IgM (solid phase assays) and its confirmation after 12 weeks. It is demanding to test for all three antibodies, hence classification in risk categories relies on single, double, or triple positivity (aPL profile, - Table 1 ). ${ }^{3}$

Clinical features are mainly venous or arterial thrombosis even in small vessels, but there are several more symptoms and other organs can be involved, partly noncriteria APS (listed in -Fig. 1).

Obstetrical complications in combination with aPL are referred to obstetric antiphospholipid syndrome (OAPS) versus thrombotic APS (TAPS). ${ }^{4}$ In this entity, pregnancy morbidity is defined either as early recurrent fetal loss (RFL), late fetal loss, stillbirth, or premature birth $<34$ weeks of gestation due to ischemic placental insufficiency. Ischemic placental insuffi-

Table 1 High-risk and low-risk aPL profile

\begin{tabular}{|c|c|}
\hline High risk & Lower risk \\
\hline $\begin{array}{l}\text { - LA positivity } \\
\text { - Triple positivity } \\
\text { (LA }+ \text { aCL }+ \text { anti-B2GPI) } \\
\text { - Isolated persistently } \\
\text { positive aCL at } \\
\text { medium-high titers } \\
\text { (studied only in } \\
\text { patients with SLE) }\end{array}$ & $\begin{array}{l}\text { - Isolated, intermittently } \\
\text { positive aCL or anti- } \beta 2 \mathrm{GPI} \\
\text { at low-medium titers }\end{array}$ \\
\hline
\end{tabular}

Abbreviations: aCL, anticardiolipin; aPL, antiphospholipid antibody; LA, lupus anticoagulant; SLE, systemic lupus erythematosus. ciency can also result in fetal growth restriction, pre-/eclampsia, HELLP (hemolysis, elevated liver enzymes, low platelet count) syndrome as well as placental abruption.

Later in life such women can also be at higher risk for TAPS depending on their antibody profile and additional cardiovascular risk factors. 5

Awareness and accurate diagnosis of OAPS are cornerstones for appropriate management in such women to prevent the deleterious results of this acquired disorder.

\section{History}

In 1975, the association between a circulating anticoagulant (LA) and early RFL was reported by Nilsson et al (in 1975) for the first time ${ }^{7}$ and in 1984, this association was described for the presence of aCL antibodies as well by Hughes et al. ${ }^{8}$ Initially, this association was described in women with systemic lupus erythematosus (SLE), ${ }^{9}$ later it was recognized as a "stand alone" autoimmune disease (primary APS). Already in the mid-1980s, the association of aPL with vascular pregnancy complications (others than RFL) was described in a small case series. ${ }^{10,11}$

\section{Prevalence}

Epidemiological data rely on correct classification. Due to high interassay and interlaboratory variations, the prevalence of aPL in healthy individuals and the prevalence of APS in the same population were not exactly clear ${ }^{12}$ and probably were overestimated in many historic studies. However, despite significant efforts toward better standardization of solid-phase assays and determination of LA, it was not achieved for decades. $^{13,14}$

The incidence of APS in Caucasians is approximately 2 to 5 per 100,000 individuals (age $>18$ years) per year and the prevalence is approximately 40 to 50 per 100,000 individuals. ${ }^{15,16}$ In blood donors (considered as healthy population), low-titer aPL can be found in 1 to $5 \%$ and is increasing with age. ${ }^{17}$

Depending on the clinical setting, the prevalence of aPL varies and is highest in patients with SLE with a 30 to $40 \%$ prevalence of any aPL. ${ }^{18,19}$ Of those, 20 to $50 \%$ will develop thrombosis. ${ }^{20,21}$

In women with pregnancy morbidity, 6\% were tested positive for aPL; for the group of women with RFL, 9\% were positive. ${ }^{22,23}$ However, a precise estimate cannot be given. Study results are conflicting, since many were performed before 2006 and thus did not follow the current classification. ${ }^{1}$ Most were retrospective analyses and only $11 \%$ of papers reported results on all three aPL criteria. Women with low-titer aPL, not fulfilling the criteria, had comparable poor pregnancy outcomes than women with high titer. ${ }^{24}$ Others could demonstrate good pregnancy outcomes with low-titer aPL. ${ }^{25}$ Moreover, the prevalence of high-titer aPL in women with RFL $<10$ weeks is questioned. ${ }^{23}$

\section{Definition-Laboratory Criteria and Testing}

Laboratory testing has to follow the strict recommendations $^{26}$ for appropriate diagnosis to avoid overdiagnosing and overtreatment in otherwise healthy pregnant women. Only a transient detection of aPL (e.g., triggered by infection) does not fulfill the criteria. 


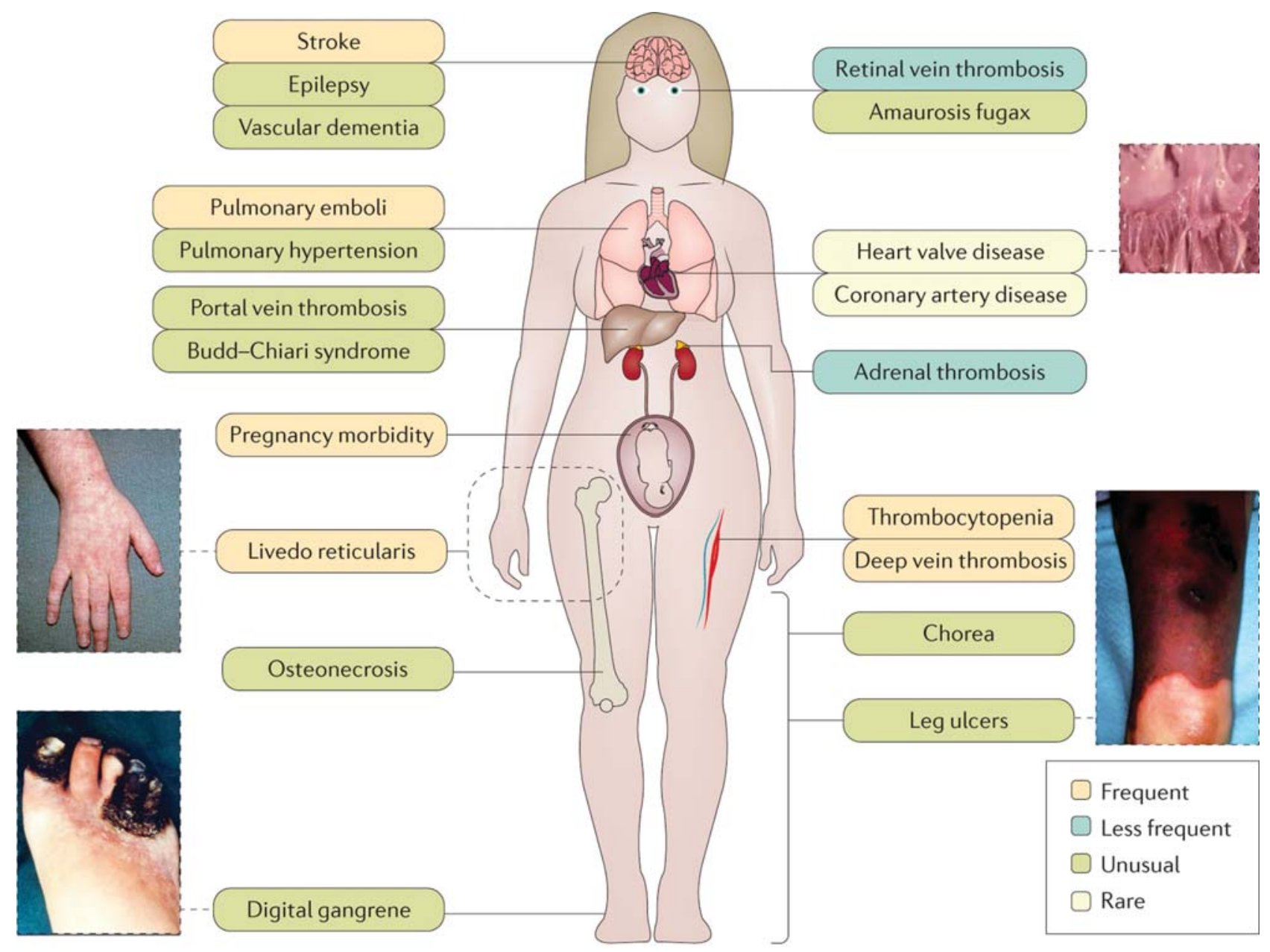

Nature Reviews | Disease Primers

Fig. 1 Clinical manifestation of antiphospholipid syndrome ${ }^{29}$ (Reprinted from [94] with permission from Springer Nature) [rerif].

Although it is unlikely that in triple-positive's results will change after 12 weeks, retesting is still necessary due to the poor standardization and other interferences which can alter test results, and to ensure the diagnosis.

Besides the recommended antibody panel to detect OAPS, other antibodies have been evaluated but are not part of the current recommendation, e.g., isotype IgA, anti-annexin V, and anti-phosphatidyl serine/prothrombin. ${ }^{27}$

\section{Pathophysiology}

Despite many years of research, the exact mechanism by which aPL induces thrombosis remains not yet fully understood. aPL can activate several cells (endothelial cells, monocytes, and platelets) and coagulation factors and the procoagulant state is caused by enhanced synthesis of tissue factor and thromboxane A2. ${ }^{28}$ Hypercoagulability in APS is due to impaired fibrinolysis, activation of prothrombin, and altered protein $C$ pathway. Further activation of the complement cascade promotes clot formation. Trauma, surgery, infections, or oxidative stress causing tissue damage and systemic inflammation may be a trigger and lead to formation of immune complexes on the cell surface. This can also explain why not every individual positive for aPL will develop clinical symptoms. Pregnancy by itself provides a possible trigger (hypercoagulable state) in the presence of anti- $\beta 2$ GPI antibodies and therefore makes women with aPL susceptible to complications. Genetic (e.g., familial APS) and environmental factors (smoking, estrogen-containing contraceptives) also play a role. ${ }^{29}$ During the last few years it has been observed that antibodies directed against domain- 1 of the $\beta 2$-GPI molecule are more pathogenic ${ }^{30}$ and associated with triple positivity. ${ }^{31}$ Such antibodies may be associated with mainly late-pregnancy complications. ${ }^{32}$

Regarding the pathomechanism in OAPS, our current knowledge is based partially on animal studies. They confirmed that aPL-related pregnancy complications are caused by inflammation and thrombosis. The effects of aPL on trophoblast cells are reduction in cell proliferation and migration, triggering secretion of inflammatory cytokines, activation of the complement system, mitochondrial disruption, and deportation of syncytial nuclear aggregates and other microvesicles. ${ }^{33,34}$

Complications after 12 weeks of gestation later in pregnancy like intrauterine growth restriction (IUGR), stillbirth, and other results of placental insufficiency are due to thrombotic (e.g., placenta infarcts) and inflammatory changes. The studies by Salmon and coworkers in a mice model clearly 
demonstrated that activation of complement plays a major role in APS, since mice with complement deficiency or its blockade protected animals from aPL-mediated fetal loss and clotting as did the infusion of heparin, which has anticomplement properties (in contrast to fondaparinux). ${ }^{35,36}$ A study on human placentae of women with aPL also demonstrated complement activation. ${ }^{37}$ A recent study confirmed this finding and histologic examinations showed vasculopathy and intervillous thrombi as the most common finding in OAPS placentae. ${ }^{38}$

Furthermore, treatment of catastrophic, multiorgan thrombi in APS with eculizumab, a complement blocking agent, ${ }^{39,40}$ supports the role of complement activation in APS and will have implication on therapeutic perspectives especially in women who fail standard of care ${ }^{41}$ and other therapies may emerge in the future. ${ }^{33}$ The scientific discussion is still ongoing ${ }^{42}$ and could result in additional therapeutic concepts.

\section{Clinical Manifestations of OAPS}

Recurrent Early Fetal Losses

Approximately $15 \%$ of clinically recognized pregnancies end before 12 weeks of gestation (definition by Royal College of Obstetricians and Gynaecologists [RCOG, Green top guideline No. 17] $)^{43}$ and a multitude of possible causes has to be considered including infections, endocrine or immune factors as well as chromosomal or structural abnormalities and aPL. Rai et al published in 1995 results on a cohort of 500 women with RFL, of which $10 \%$ were LA positive, aCL IgG was detected in $3.3 \%$, and IgM in $2.2 \%$ of patients. ${ }^{44}$ If aPL are detected, treatment of RFL is possible and based on clinical trials. ${ }^{45}$

\section{Late Pregnancy Losses}

Definition varies and in Germany fetal loss $>12$ and $<22$ weeks of gestation is included (the so-called late miscarriage); after 20 to 22 weeks of gestation the term stillbirth or intrauterine fetal death (IUFD) is used. Only one study has been published on stillbirth and aPL. The authors reported a detection rate of $11.1 \%$ (95\% confidence interval [CI]: 8.414.4) for aCL antibodies in 512 cases of stillbirth. ${ }^{46}$ However, the study has limitations: LA was not analyzed and abnormal results were not confirmed 12 weeks apart.

Preeclampsia and Other Signs of Placental Insufficiency Placental insufficiency due to reduced maternal blood flow to the placenta causes mainly late pregnancy complications like IUGR, stillbirth, placental abruption, and PE.

In developed countries IUGR is seen in 2 to $8 \%$ of pregnancies. In women with OAPS, 12 to $30 \%$ will develop IUGR (earlier study). ${ }^{47}$ Even with treatment (low-dose aspirin $[\mathrm{LDA}]+$ low-molecular-weight heparin [LMWH]), the rate of IUGR is still $23 \%{ }^{48}$

$\mathrm{PE}$ (defined by new hypertension and proteinuria after the 20 th week of gestation) occurs in $<5 \%$ of pregnancies, but increases to $17.3 \%$ in APS pregnancies and $22.5 \%$ in SLE pregnancies. $^{49}$
Only $0.5 \%$ of pregnant women will develop severe PE. Usually severe, rapidly progressing PE with multiorgan involvement occurs before 34 weeks of gestation (early onset). In contrast, late-onset PE is often less severe. PE is related to increased maternal and fetal morbidity and mortality. ${ }^{50}$

Premature birth due to placental insufficiency or to severe PE prior to 34 weeks of gestation is a clinical sign of OAPS. The association of moderate-to-high titer aCL with these clinical symptoms has been described by several retro- and prospective studies. ${ }^{51,52}$ The review article summarizes the dilemma well; earlier case-control studies have overestimated the association (up to $30 \%$ aCL pos. in women with $\mathrm{PE}$ ) due to selection bias, use of different aPL assays, poor interlaboratory comparisons, lack of standardization, and improper definition of APS. ${ }^{52}$ Others reported pregnancy morbidity due to aPL in only $6 \%$ of the pregnant population in general. ${ }^{22}$ With recommended treatment 17.6 versus $59.6 \%$ without medication will require preterm delivery prior to 34 weeks of gestation, and severe PE was seen in 6.6 versus $41.2 \%$ in the EURAPS survey. ${ }^{53}$

A meta-analysis neither showed any benefit of LMWH for the prevention of recurrent placenta-mediated pregnancy complications in women with or without aPL nor other forms of thrombophilia, except for women with previous placental abruption. ${ }^{54}$ However, out of 882 women, only 31 (4\%) were classified as aPL positive. Therefore, one should not question the current recommendations, since the reported numbers and event rates for women with aPL were too small.

Up to now it is accepted that women who fulfill the laboratory and clinical criteria for APS have a higher risk for developing PE/HELLP syndrome, IUGR, or stillbirth. Therefore intense surveillance is essential.

IUFD is the most specific and recurrent early abortion is the most sensitive clinical symptom, but less specific due to a lot of other unknown reasons. ${ }^{1}$

\section{Results of Recent Management Studies}

So far there has been only the FRUIT trial ${ }^{55}$ aiming on management and prevention of PE and IUGR in women with aPL and previous adverse pregnancy outcome (APO). The researchers compared LDA ( $80 \mathrm{mg}$ ) versus LDA + LMWH (dalteparin 5,000 IU) started before 12 weeks of gestation. However, the event rate was too low for any statistical analysis. The study was stopped early and final results on 32 women enrolled in 9 years revealed no difference for both treatment groups.

The PREGNANTS study ${ }^{56}$ determined the risk of APO in women with primary APS according to their aPL profile. The authors evaluated 750 singleton pregnancies. In total, 85.3\% ( $n=640$ ) were single positive only for LA/aCL/abeta2-GPI and $14.7 \%(n=110)$ had $>1$ positive antibody. Despite receiving treatment with LDA + LMWH from first trimester on, in the group of single positives, severe $\mathrm{PE}<34$ weeks of gestation and IUGR was detected in $45.3 \%$; fetal death $>10$ weeks of gestation in $25 \%$, not significantly different from the women with more than one antibody positive $(45.5 \%$ and $27.3 \%$, respectively). Not surprisingly, the rate of vascular thrombosis in the group of double or triple positives was 
significantly higher, 31.8 versus $13.1 \%(p<0.01)$. The adjusted odds ratio $(\mathrm{OR} ; 95 \% \mathrm{CI})$ were calculated for severe PE: 1.66 (1.19-2.79) and for nonsevere PE: 1.55 (1.20-1.95), for IUGR: 2.29 (1.07-2.65), and for stillbirth: 2.13 (1.12-1.95). In women being only single positive, abeta2-GPI was the one associated with the highest rate of APO when compared with LA or aCL alone.

Until today, randomized clinical trials have failed to prove if LMWH is beneficial for APS women with late pregnancy complications. However, the recommendation to use LMWH for prophylaxis of recurrent complications is part of current standard therapy.

\section{Preconceptional Counseling}

Before anticoagulant treatment was introduced in the late 1980 s, only 20 to $30 \%$ of women with APS/OAPS had a live birth. Since then the live birth rate increased to approximately 70 to $80 \%{ }^{57}$ But even those pregnancies are at a higher risk for early PE in 10 to $17 \%$, IUGR in 15 to $23 \%,{ }^{48}$ placentamediated complications in $19 \%$, and preterm delivery in 17 to $26 \%{ }^{53,57}$

The following risk estimates can be given:

The presence of LA has been described as the best predictor for OAPS and ${ }^{58}$ triple positivity ( $+\mathrm{LA}+\mathrm{aCL}+$ abeta2GPI) correlates with a higher risk for TAPS. ${ }^{5}$

Women with persistent LA still have a high risk of APO despite anticoagulant treatment $70 \%$ of the cohort [OR: 4.51; 95\% CI: $1.08-18.93]) .{ }^{59}$ The reported live birth rate was $54 \%$ (15/28 pregnancies) for women on treatment with LDA + LMWH versus $3 / 12(25 \%)$ receiving none or a single agent.

Considering the small number, the subgroup analysis of the PROMISSE study revealed a live birth rate of $31 \%$. In this subgroup of 44 women with or without SLE but positive for aPL (30\%), APO occurred in $80 \%$ in the two trimesters. LA was present in $69 \%$ of pregnancies and only in $27 \%$ of pregnancies without APO $(p=0.01){ }^{60}$ There was no correlation with aCL or abeta2-GPI and APO (neither IgG nor IgM positivity). Independent of the diagnosis of SLE, the APO rate in women with previous OAPS or TAPS was $92 \%$ versus $45 \%$ in women without history $(p=0.004)$. This study did not include RFL $<12$ weeks, which were the most frequent APOs in the Vienna study ${ }^{59}$.

Even in the larger cohort of the PREGNANTS study, ${ }^{56}$ the live birth rate was $57 \%$ for single and $41 \%$ for double or triple positives. Interestingly, looking at the aPL profile, live birth rate was $80 \%$ in 54 women who were LA positive only (7\%). This live birth rate was much higher than in women with aCL only ( $61 \%$ of the cohort, $56 \%$ live birth rate); only 20 women (3\%) were triple positive with the lowest birth rate of only $30 \%$. These figures are somewhat in contrast with published data on a live birth rate of 70 to $80 \%$ achieved with current treatments. The aPL profile has to be considered when counseling. The high-risk profile of aPL ( - Table 1 ) correlates with the high risk for OAPS (OR: 12.1), ${ }^{61}$ PE (OR: 2.3), IUGR (OR: 4.7), ${ }^{62}$ APS-related pregnancy morbidity (OR: 9.2), ${ }^{63}$ and preterm birth. A lower risk of APO had been reported for isolated aCL or abeta2-GPI. ${ }^{64} \mathrm{~A}$ detection rate of $11 \%(95 \%$
CI: 8.4-14.4) for aCL antibodies has been reported in 512 cases of stillbirth. ${ }^{46}$

In May 2019, a published meta-analysis ${ }^{65}$ combining eight recent, observational, retro- and prospective studies with 770 cases of OAPS and 212,184 controls revealed the following risk ratios (RRs) of APO in women with aPL.

RFL RR: 1.33 (95\% CI: 1.00-1.76, $p=0.05$ ); abortion RR: 2.42 (95\% CI: $1.46-4.01, p=0.0006$ ); thrombosis RR: 2.83 (95\% CI: $1.47-5.44, p=0.002$ ); pregnancy-induced hypertension RR: 1.81 (95\% CI: $1.33-2.45, p=0.0002$ ); preterm delivery RR: 1.89 (95\% CI: $1.52-2.35, p=0.00001$ ), regarding fetal outcome neonatal mortality RR: 3.95 (95\% CI: 1.987.86, $p=0.0001)$; small for gestational age RR: 1.38 (95\% CI: 1.04-1.82.45, $p=0.02$ ); premature infants RR: 1.86 (95\% CI: $1.52-2.28, p=0.00001$ ); and admission to neonatal ICU RR: 3.35 (95\% CI: 2.29-4.89, $p=0.00001$ ).

\section{Predictors for Positive Pregnancy Outcome}

- Low risk profile of aPL ( - Table 1 ). ${ }^{4}$

- Previous pregnancy with successful outcome. ${ }^{66}$

- Normal end-diastolic blood flow in the uterine artery at gestational weeks 20 to $24 .{ }^{67}$

\section{Predictors for Adverse Pregnancy Outcome}

- History of TAPS.

- Triple positivity or high risk profile.

- Reduced flow in uterine arteries measured by Doppler velocimetry is an indirect indication for placental insufficiency and/or PE. ${ }^{68}$

\section{Treatment}

Primary treatment regimen (LDA and LMWH) is focused on preventing thrombosis. However, the current recommendation fails in 20 to $30 \%$, especially in women with a high risk aPL profile for thrombosis (triple positivity or strong LA).

\section{Current Treatment Recommendations}

Today most guidelines recommend preconceptional LDA and/or LMWH for women with OAPS in the next pregnancy (RCOG: unfractionated heparin as an option if LMWH might be contraindicated). Long-term use of unfractionated heparin carries a risk for osteoporosis and if chosen, the woman has to inject it two to three times daily due to the short halflife and lower bioavailability.

First-line recommendations:

- Summarized in -Table 2 and are based on currently published guidelines. ${ }^{69,70}$

Second-line recommendations:

- Addition of $10 \mathrm{mg}$ prednisolone from positive pregnancy test until 14 weeks of gestation. ${ }^{71,72}$

- Treatment with intravenous IgG did not show any benefit (has side effects and is costly). ${ }^{73}$

\section{Further Treatment Option-Near Future}

Statins in this context are not used to reduce cholesterol. They reduce inflammation, oxidative stress, and therefore are protective for the endothelium. Additionally, their effect 
Table 2 Management of pregnant women with antiphospholipid antibodies or APS

\begin{tabular}{|c|c|c|}
\hline Clinical manifestation & Treatment & Evidence \\
\hline $\begin{array}{l}\text { Persistent presence of antiphospholipid } \\
\text { antibodies during first pregnancy or before } \\
\text { the first pregnancy without previous } \\
\text { adverse pregnancy outcomes }\end{array}$ & $\begin{array}{l}\text { Close monitoring of fetus and mother } \\
\text { during pregnancy with or without } \\
\text { LDA treatment }\end{array}$ & $\begin{array}{l}\text { Data support the use of LDA to prevent } \\
\text { preeclampsia in high-risk pregnancies, } \\
\text { but no studies have been performed in } \\
\text { APS; treatment decision should be } \\
\text { made on an individual basis }\end{array}$ \\
\hline $\begin{array}{l}\text { Persistent positivity for antiphospholipid } \\
\text { antibodies and history of recurrent } \\
\text { first-trimester pregnancy loss } \\
\text { (without previous thrombosis) }\end{array}$ & $\begin{array}{l}\text { LDA }^{\text {a }} \text { with or without prophylactic } \\
\text { LMWH or unfractionated heparin }\end{array}$ & $\begin{array}{l}\text { Low-quality randomized controlled } \\
\text { trials }\end{array}$ \\
\hline $\begin{array}{l}\text { History of miscarriage or previous history } \\
\text { of ischemic placental-mediated complica- } \\
\text { tions (second-trimester complications) }\end{array}$ & $\begin{array}{l}\text { LDA }^{\text {a }} \text { with prophylactic } \\
\text { unfractionated heparin }\end{array}$ & $\begin{array}{l}\text { Low-quality randomized controlled } \\
\text { trials }\end{array}$ \\
\hline $\begin{array}{l}\text { Patients with thrombotic APS (venous or } \\
\text { arterial) }\end{array}$ & $\begin{array}{l}\text { LDA }^{a} \text { and intermediate-dose or } \\
\text { high-dose LMWH }\end{array}$ & $\begin{array}{l}\text { Based on one prospective observational } \\
\text { study }\end{array}$ \\
\hline $\begin{array}{l}\text { Postpartum presence of antiphospholipid } \\
\text { antibodies }\end{array}$ & $\begin{array}{l}\text { LMWH thromboprophylaxis for } 1-6 \\
\text { weeks postpartum on an individual } \\
\text { basis depending on the presence of } \\
\text { additional risk factors for thrombosis. } \\
\text { Women with thrombotic APS can } \\
\text { restart anticoagulation once } \\
\text { hemostasis is achieved. Vitamin } \mathrm{K} \\
\text { antagonists }{ }^{\complement} \text { are safe while breast- } \\
\text { feeding; no safety data on DOACs are } \\
\text { available }\end{array}$ & $\begin{array}{l}\text { Based on case-control studies and } \\
\text { cohort studies }\end{array}$ \\
\hline
\end{tabular}

Abbreviations: APS, antiphospholipid syndrome; DOACs, direct oral anticoagulants; LDA, low-dose aspirin; LMWH, low-molecular-weight heparin. aLDA: $100-150 \mathrm{mg}$.

'Thrombophrophylactic dose for high-risk situations: approximately 4,000 units.

'Only warfarin, not phenprocoumon (Marcumar ${ }^{\circledR}$ ).

on angiogenesis and the coagulation cascade may prevent pregnancy complications as has been observed in animal studies. $^{74}$

A small study revealed promising results: the addition of a statin (pravastatin) to standard of care could reverse aPLinduced gestational hypertension and PE. ${ }^{75}$ Safety and efficacy of statins in pregnant women with APS who develop PE despite treatment with ASA and LMWH is still on the research agenda (EULAR update APS 2019). ${ }^{76}$

Hydroxychloroquin (HCQ) has been used as an immunemodulating drug in SLE for many years. In SLE women planning to become pregnant and especially in women with anti-Ro/SSA or anti-La/SSB-antibodies, it is a cornerstone in preventing pregnancy complications as well as protecting the child, reducing the chance for neonatal lupus, and completes congenital heart block. ${ }^{72}$

In retrospective studies, its beneficial effect in non-SLE women with OAPS has been documented. ${ }^{77,78}$ In the study by Mekinian et al, 35 pregnancies were observed. Treatment with HCQ reduced first trimester losses from 81 to $19 \%$ $(p<0.05)$ and live birth rate increased to $78 \%(p<0.05)$. The significant reduction of all forms APO when adding HCQ to standard of care was confirmed by the second study with OR 2.2 (95\% CI: $1.2-136.1 ; p=0.04$ ). The same group is running a prospective study in France. ${ }^{78}$

Based on these promising data, the use of HCQ has been encouraged as an option for women with previous treatment failure $^{80}$; even though a prospective, multicenter random- ized European trail (HYPATIA-HCQ to improve pregnancy outcome in women with aPL) is still ongoing.

The urgent need for further options in women with APS (non-SLE) has granted the European Medicines Agency (EMA) to approve HCQ for treatment and prevention (e.g., thrombosis) in summer 2019 (EMA, orphan designation [EU/3/16/1820] 2018).

Noteworthy, the IMPACT trial (NCT03152058) is testing the drug certolizumab for prevention of APO in women with APS/aPL carriers (pos. LA). Certolizumab is a PEGylated antiTNF $\alpha$ antibody that prevents complement-dependent and antibody-dependent cell-mediated cytotoxicity or apoptosis.

\section{Special Aspects}

Women with SLE

This subgroup of women is at enhanced risk and more than $20 \%$ will suffer pregnancy losses and late pregnancy complications (IUGR, PE, and premature birth) are more common, and especially a high risk aPL-profile is associated with APO. ${ }^{81}$ In a Stockholm cohort, $12 \%$ of SLE women were triple positive and $20 \%$ were positive for LA only. ${ }^{82}$ Such profiles are correlated with APO and thrombosis. SLE patients with TAPS are also at a higher risk. ${ }^{83}$ The PROMISSE study analyzed 385 women with SLE and $19 \%$ had APO. A strong predictor was LA positivity at baseline with an OR 8.3 (95\% CI: 3.6-19.3). Similar results have been reported for the Hopkins-Lupus cohort ${ }^{84}$; in 202 pregnancies, early fetal loss was documented in $38 \%$ of LA-positive as compared with $9 \%$ LA-negative women. 
In 2017, EULAR recommendations focusing on women's health issues were published. ${ }^{72}$ The importance of early counseling for family planning was pointed out. Therefore, all SLE women should be tested for aPL when planning a pregnancy, including the anti-Ro/SSA and anti-La/SSB status to advise individualized prophylaxis and medication.

HCQ: the immunomodulatory effect of this traditional antimalaria drug is well known. The drug is current treatment standard in patients with autoimmune diseases, mainly SLE. ${ }^{85}$ It was shown that HCQ prevents SLE flares, has antiinflammatory and antithrombotic effects. ${ }^{86}$ Therefore, it improves outcome in nonpregnant and pregnant SLE patients. Treatment should be implemented in SLE women planning to become pregnant if not given before. ${ }^{76} \mathrm{HCQ}$ is recommended preconceptionally and throughout pregnancy in women with SLE. No teratogenic side effects have been documented and breast feeding is feasible.

\section{aPL Carriers}

These are individuals with incidentally detected persistent aPL (e.g., preoperative prolonged aPTT, infertility work-up, screening in families with autoimmune disease [SLE]). In the absence of any clinical symptom, they do not fulfill the criteria for APS. Also individuals presenting with "noncriteria" symptoms like thrombocytopenia or livedo reticularis are included in this group as well as SLE patients with aPL. Recently a study on 62 pregnancies in aPL carriers showed association with pregnancy complications similar to APS. ${ }^{79}$ APO and thrombosis were observed in 12.9\%. Despite antithrombotic prophylaxis (LDA and LMWH), the complication rate was high: OR 21.3 (95\% CI: $1.84-247)(p=0.01)$. Since the risk of bleeding during pregnancy is low, one should not hesitate to recommend treatment and to start LDA before conception as recommended for women with APS. ${ }^{87}$

Since SLE patients classified as aPL carriers are at increased risk for vascular morbidity, primary prophylaxis with LDA has shown to reduce the risk ${ }^{88}$ and is part of the recent EULAR recommendation. ${ }^{89}$

LDA for primary prophylaxis in asymptomatic carriers is still on debate. The recent EULAR update recommends LDA based on a meta-analysis, which revealed a benefit in preventing arterial but not venous thrombosis. However, only in high-risk situations thromboprophylaxis with LMWH should be considered. ${ }^{76}$

\section{Children Born to Mothers with OAPS-The View of a Pediatrician}

Maternal aPL isotype IgG can cross the placenta and has been found in up to $30 \%$ of newborns ${ }^{90}$ and will vanish during the first year of life. Luckily, neonatal thrombosis due to aPL is rare. ${ }^{91}$ Because of the incompleteness of the fetal bloodbrain barrier, aPL could theoretically reach the fetal brain. Whether it can have an effect on brain development is still under investigation. Evaluation of neurodevelopmental abnormalities is difficult and influenced by a variety of risk factors like prematurity or reduced birth weight and other maternal factors have to be considered. The long-term neurodevelopmental outcome of such children was studied and revealed a normal intelligence level, but 3 out of $16(19 \%)$ older children were diagnosed with learning disabilities (approximately $3 \%$ in general pediatric population). ${ }^{92}$ The three mothers were triple positive. Epilepsy was also more frequently diagnosed (10\%) in such children. In 2017 the SHARE initiative was launched to provide evidence-based recommendations for diagnosis and treatment of pediatric APS as well as for children born to mothers with OAPS. ${ }^{93}$

\section{Summary}

Even though OAPS is known for more than three decades, the awareness for this disease in women with or without SLE is still low in medical care providers, unfortunately. OAPS is a treatable cause of early recurrent miscarriage and vascular pregnancy complications, otherwise resulting in APOs, preterm delivery, and is harmful for the mother and child. Current treatment options are LDA (given preconceptionally) and, depending on the risk profile of the women (prior thrombosis, aPL status), prophylactic, intermediate, or therapeutic doses of LMWH. A live birth rate of 70 to $80 \%$ can be achieved with this strategy. Women of reproductive age with OAPS or aPL carriers should be encouraged to plan for another pregnancy. However, the health status of the women has to be determined, especially in a woman with underlying autoimmune disease (e.g., SLE, renal disease) or uncontrolled hypertension. And in women with an arterial or venous thrombosis in the last three months, pregnancy should be postponed. It is an "ultima ratio" to offer counseling and have a management plan for the next pregnancy. A multidisciplinary approach is needed for such couples, desperate to have a successful pregnancy.

Currently, one study is still ongoing to support the evidence of HCQ as an additional treatment option for women failing established treatment recommendations. Since there is an urgent need for further options in women with APS (non-SLE), EMA has granted approval of HCQ for treatment and prevention in summer 2019. Further prospective studies will help to find personalized new treatments for different aPL profiles and especially high-risk women with comorbidities. Prevention of pregnancy complication in women with APS starts with its detection. This comprehensive review intends to spread the knowledge and helps affected women to receive state-of-the-art treatment.

Conflict of Interest

The authors declare that they have no conflict of interest.

\section{References}

1 Miyakis S, Lockshin MD, Atsumi T, et al. International consensus statement on an update of the classification criteria for definite antiphospholipid syndrome (APS). J Thromb Haemost 2006;4 (02):295-306

2 McDonnell T, Wincup C. Buchholz I, et al. The role of beta-2glycoprotein I in health and disease associating structure with function: more than just APS. Blood Rev 2020;39:100610

3 Pengo V, Biasiolo A, Pegoraro C, Cucchini U, Noventa F, Iliceto S. Antibody profiles for the diagnosis of antiphospholipid syndrome. Thromb Haemost 2005;93(06):1147-1152 
4 de Jesus GR, Agmon-Levin N, Andrade CA, et al. 14th International Congress on Antiphospholipid Antibodies Task Force report on obstetric antiphospholipid syndrome. Autoimmun Rev 2014;13 (08):795-813

5 Pengo V, Ruffatti A, Legnani C, et al. Incidence of a first thromboembolic event in asymptomatic carriers of high-risk antiphospholipid antibody profile: a multicenter prospective study. Blood 2011;118(17):4714-4718

6 Gris JC, Bouvier S, Molinari N, et al. Comparative incidence of a first thrombotic event in purely obstetric antiphospholipid syndrome with pregnancy loss: the NOH-APS observational study. Blood 2012;119(11):2624-2632

7 Nilsson IM, Astedt B, Hedner U, Berezin D. Intrauterine death and circulating anticoagulant ("antithromboplastin"). Acta Med Scand 1975;197(03):153-159

8 Hughes GR, Harris EN, Gharavi AE. The syndrome of thrombosis, abortion, and neurological disease. Contrib Nephrol 1984;43:9-11

9 Harris EN. Syndrome of the black swan. Br J Rheumatol 1987;26 (05):324-326

10 Lockshin MD, Druzin ML, Goei S, et al. Antibody to cardiolipin as a predictor of fetal distress or death in pregnant patients with systemic lupus erythematosus. N Engl J Med 1985;313(03): 152-156

11 Branch DW, Scott JR, Kochenour NK, Hershgold E. Obstetric complications associated with the lupus anticoagulant. N Engl J Med 1985;313(21):1322-1326

12 Radin M, Sciascia S. Infodemiology of systemic lupus erythematous using Google Trends. Lupus 2017;26(08):886-889

13 Tripodi A, Chantarangkul V, Cini M, et al. Variability of cut-off values for the detection of lupus anticoagulants: results of an international multicenter multiplatform study. J Thromb Haemost 2017;15(06):1180-1190

14 Devreese KM. Standardization of antiphospholipid antibody assays. Where do we stand? Lupus 2012;21(07):718-721

15 Durcan L, Petri M. Epidemiology of the antiphospholipid syndrome. In: Cervera R, Espinosa G, Khamashta M, eds. Handbook of Systemic Autoimmune Diseases. Vol. 12. Amsterdam: Elsevier; 2017:17-30

16 Duarte-García A, Pham MM, Crowson CS, et al. The epidemiology of antiphospholipid syndrome: a population-based study. Arthritis Rheumatol 2019;71(09):1545-1552

17 Meroni PL, Mari D, Monti D, et al. Anti-beta 2 glycoprotein I antibodies in centenarians. Exp Gerontol 2004;39(10):1459-1465

18 Mok CC, Tang SS, To CH, Petri M. Incidence and risk factors of thromboembolism in systemic lupus erythematosus: a comparison of three ethnic groups. Arthritis Rheum 2005;52(09):2774-2782

19 Taraborelli M, Lazzaroni MG, Martinazzi N, et al. The role of clinically significant antiphospholipid antibodies in systemic lupus erythematosus. Reumatismo 2016;68(03):137-143

20 Tektonidou MG, Laskari K, Panagiotakos DB, Moutsopoulos HM. Risk factors for thrombosis and primary thrombosis prevention in patients with systemic lupus erythematosus with or without antiphospholipid antibodies. Arthritis Rheum 2009;61(01): 29-36

21 Cervera R, Serrano R, Pons-Estel GJ, et al; Euro-Phospholipid Project Group (European Forum on Antiphospholipid Antibodies). Morbidity and mortality in the antiphospholipid syndrome during a 10-year period: a multicentre prospective study of 1000 patients. Ann Rheum Dis 2015;74(06):1011-1018

22 Andreoli L, Chighizola CB, Banzato A, Pons-Estel GJ, Ramire de Jesus G, Erkan D. Estimated frequency of antiphospholipid antibodies in patients with pregnancy morbidity, stroke, myocardial infarction, and deep vein thrombosis: a critical review of the literature. Arthritis Care Res (Hoboken) 2013;65(11):1869-1873

23 Bowman ZS, Wünsche V, Porter TF, Silver RM, Branch DW. Prevalence of antiphospholipid antibodies and risk of subsequent adverse obstetric outcomes in women with prior pregnancy loss. J Reprod Immunol 2015;107:59-63
24 Mekinian A, Loire-Berson P, Nicaise-Roland P, et al. Outcomes and treatment of obstetrical antiphospholipid syndrome in women with low antiphospholipid antibody levels. J Reprod Immunol 2012;94(02):222-226

25 Simchen MJ, Dulitzki M, Rofe G, et al. High positive antibody titers and adverse pregnancy outcome in women with antiphospholipid syndrome. Acta Obstet Gynecol Scand 2011;90(12):1428-1433

26 Devreese KMJ, Ortel TL, Pengo V, de Laat B; Subcommittee on Lupus Anticoagulant/Antiphospholipid Antibodies. Laboratory criteria for antiphospholipid syndrome: communication from the SSC of the ISTH. J Thromb Haemost 2018;16(04):809-813

27 Sciascia S, Sanna G, Murru V, Roccatello D, Khamashta MA, Bertolaccini ML. Anti-prothrombin (aPT) and anti-phosphatidylserine/prothrombin (aPS/PT) antibodies and the risk of thrombosis in the antiphospholipid syndrome. A systematic review. Thromb Haemost 2014;111(02):354-364

28 Pierangeli SS, Chen PP, Raschi E, et al. Antiphospholipid antibodies and the antiphospholipid syndrome: pathogenic mechanisms. Semin Thromb Hemost 2008;34(03):236-250

29 Schreiber K, Sciascia S, de Groot PG, et al. Antiphospholipid syndrome. Nat Rev Dis Primers 2018;4:17103

30 de Laat B, Pengo V, Pabinger I, et al. The association between circulating antibodies against domain I of beta2-glycoprotein I and thrombosis: an international multicenter study. J Thromb Haemost 2009;7(11):1767-1773

31 Pengo V, Ruffatti A, Tonello M, et al. Antiphospholipid syndrome: antibodies to Domain 1 of $\beta 2$-glycoprotein 1 correctly classify patients at risk. J Thromb Haemost 2015;13(05):782-787

32 Chighizola CB, Pregnolato F, Andreoli L, et al. Beyond thrombosis: anti-ß2GPI domain 1 antibodies identify late pregnancy morbidity in anti-phospholipid syndrome. J Autoimmun 2018;90:76-83

33 Abrahams VM, Chamley LW, Salmon JE. Emerging treatment models in rheumatology: antiphospholipid syndrome and pregnancy: pathogenesis to translation. Arthritis Rheumatol 2017;69(09):1710-1721

34 Garcia D, Erkan D. Diagnosis and management of the antiphospholipid syndrome. N Engl J Med 2018;378(21):2010-2021

35 Girardi G, Berman J, Redecha P, et al. Complement C5a receptors and neutrophils mediate fetal injury in the antiphospholipid syndrome. J Clin Invest 2003;112(11):1644-1654

36 Girardi G, Redecha P, Salmon JE. Heparin prevents antiphospholipid antibody-induced fetal loss by inhibiting complement activation. Nat Med 2004;10(11):1222-1226

37 Shamonki JM, Salmon JE, Hyjek E, Baergen RN. Excessive complement activation is associated with placental injury in patients with antiphospholipid antibodies. Am J Obstet Gynecol 2007;196 (02):167.e1-167.e5

38 Tedesco F, Borghi MO, Gerosa M, et al. Pathogenic role of complement in antiphospholipid syndrome and therapeutic implications. Front Immunol 2018;9:1388

39 Rovere-Querini P, Canti V, Erra R, et al. Eculizumab in a pregnant patient with laboratory onset of catastrophic antiphospholipid syndrome: a case report. Medicine (Baltimore) 2018;97(40):e12584

40 Chighizola CB, Andreoli L, Gerosa M, Tincani A, Ruffatti A, Meroni PL. The treatment of anti-phospholipid syndrome: a comprehensive clinical approach. J Autoimmun 2018;90:1-27

41 Stefanovic V. The extended use of eculizumab in pregnancy and complement activation-associated diseases affecting maternal, fetal and neonatal kidneys-the future is now? JClin Med 2019;8(03):E407

42 Lackner KJ, Müller-Calleja N. Cofactor-independent antiphospholipid antibodies: implications for pathogenesis, diagnosis, and treatment of antiphospholipid syndrome. Hamostaseologie 2019; 39(02):188-194

43 Regan L, Backos M, Rai R. The investigation and treatment of couples with recurrent firsttrimester and second-trimester miscarriage [Green-top Guideline No. 17]. Royal College of Obsetrican \& Gynaecologists. 2011:1-18. Available at: https:// www.rcog.org.uk/globalassets/documents/guidelines/gtg_17.pdf. Accessed February 17, 2020 
44 Rai RS, Regan L, Clifford K, et al. Antiphospholipid antibodies and beta 2-glycoprotein-I in 500 women with recurrent miscarriage: results of a comprehensive screening approach. Hum Reprod 1995;10(08):2001-2005

45 Cohn DM, Goddijn M, Middeldorp S, Korevaar JC, Dawood F, Farquharson RG. Recurrent miscarriage and antiphospholipid antibodies: prognosis of subsequent pregnancy. J Thromb Haemost 2010;8(10):2208-2213

46 Page JM, Christiansen-Lindquist L, Thorsten V, et al. Diagnostic tests for evaluation of stillbirth: results from the stillbirth collaborative research network. Obstet Gynecol 2017;129(04):699-706

47 Lima F, Khamashta MA, Buchanan NM, Kerslake S, Hunt BJ, Hughes GR. A study of sixty pregnancies in patients with the antiphospholipid syndrome. Clin Exp Rheumatol 1996;14(02):131-136

48 Högdén A, Antovic A, Berg E, Bremme K, Chaireti R. Obstetric outcomes in patients with primary thrombotic and obstetric antiphospholipid syndrome and its relation to the antiphospholipid antibody profile. Lupus 2019;28(07):868-877

49 Bartsch E, Medcalf KE, Park AL, Ray JG; High Risk of Pre-eclampsia Identification Group. Clinical risk factors for pre-eclampsia determined in early pregnancy: systematic review and meta-analysis of large cohort studies. BMJ 2016;353:i1753

50 Schlembach D, Stephan H. Hypertensive Schwangerschaftserkrankungen: Diagnostik und Therapie (Registernummer 015-018). Arbeitsgemeinschaft der Wissenschaftlichen Medizinischen Fachgesellschaften2019:1-117. Available at: https:// www.awmf.org/uploads/tx_szleitlinien/015-0181_S2k_Diagnostik_Therapie_hypertensiver_Schwangerschaftserkrankungen_2019-07.pdf. Accessed February 17, 2020

51 Yamada H, Atsumi T, Kobashi G, et al. Antiphospholipid antibodies increase the risk of pregnancy-induced hypertension and adverse pregnancy outcomes. J Reprod Immunol 2009;79(02):188-195

52 do Prado AD, Piovesan DM, Staub HL, Horta BL. Association of anticardiolipin antibodies with preeclampsia: a systematic review and meta-analysis. Obstet Gynecol 2010;116(06):1433-1443

53 Alijotas-Reig J, Esteve-Valverde E, Ferrer-Oliveras R, et al; EUROAPS Study Group. The European Registry on Obstetric Antiphospholipid Syndrome (EUROAPS): a survey of 1000 consecutive cases. Autoimmun Rev 2019;18(04):406-414

54 Rodger MA, Langlois NJ, de Vries JI, et al. Low-molecular-weight heparin for prevention of placenta-mediated pregnancy complications: protocol for a systematic review and individual patient data meta-analysis (AFFIRM). Syst Rev 2014;3:69

55 van Hoorn ME, Hague WM, van Pampus MG, Bezemer D, de Vries JI; FRUIT Investigators. Low-molecular-weight heparin and aspirin in the prevention of recurrent early-onset pre-eclampsia in women with antiphospholipid antibodies: the FRUIT-RCT. Eur J Obstet Gynecol Reprod Biol 2016;197:168-173

56 Saccone G, Berghella V, Maruotti GM, et al; PREGNANTS (PREGNancy in women with ANTiphospholipid Syndrome) working group. Antiphospholipid antibody profile based obstetric outcomes of primary antiphospholipid syndrome: the PREGNANTS study. Am J Obstet Gynecol 2017;216(05):525.e1-525.e12

57 Bouvier S, Cochery-Nouvellon E, Lavigne-Lissalde G, et al. Comparative incidence of pregnancy outcomes in thrombophiliapositive women from the NOH-APS observational study. Blood 2014;123(03):414-421

58 Galli M, Luciani D, Bertolini G, Barbui T. Lupus anticoagulants are stronger risk factors for thrombosis than anticardiolipin antibodies in the antiphospholipid syndrome: a systematic review of the literature. Blood 2003;101(05):1827-1832

59 Gebhart J, Posch F, Koder S, et al. High risk of adverse pregnancy outcomes in women with a persistent lupus anticoagulant. Blood Adv 2019;3(05):769-776

60 Yelnik CM, Laskin CA, Porter TF, et al. Lupus anticoagulant is the main predictor of adverse pregnancy outcomes in aPL-positive patients: validation of PROMISSE study results. Lupus Sci Med 2016;3(01):e000131
61 Stone S, Hunt BJ, Khamashta MA, Bewley SJ, Nelson-Piercy C. Primary antiphospholipid syndrome in pregnancy: an analysis of outcome in a cohort of 33 women treated with a rigorous protocol. J Thromb Haemost 2005;3(02):243-245

62 Abou-Nassar K, Carrier M, Ramsay T, Rodger MA. The association between antiphospholipid antibodies and placenta mediated complications: a systematic review and meta-analysis. Thromb Res 2011;128(01):77-85

63 Ruffatti A, Tonello M, Visentin MS, et al. Risk factors for pregnancy failure in patients with anti-phospholipid syndrome treated with conventional therapies: a multicentre, case-control study. Rheumatology (Oxford) 2011;50(09):1684-1689

64 Ruffatti A, Calligaro A, Hoxha A, et al. Laboratory and clinical features of pregnant women with antiphospholipid syndrome and neonatal outcome. Arthritis Care Res (Hoboken) 2010;62(03):302-307

65 Liu L, Sun D. Pregnancy outcomes in patients with primary antiphospholipid syndrome: a systematic review and meta-analysis. Medicine (Baltimore) 2019;98(20):e15733

66 Ruiz-Irastorza G, Crowther M, Branch W, Khamashta MA. Antiphospholipid syndrome. Lancet 2010;376(9751):1498-1509

67 Hunt BJ, Missfelder-Lobos H, Parra-Cordero M, et al. Pregnancy outcome and fibrinolytic, endothelial and coagulation markers in women undergoing uterine artery Doppler screening at 23 weeks. J Thromb Haemost 2009;7(06):955-961

68 Le Thi Huong D, Wechsler B, Vauthier-Brouzes D, et al. The second trimester Doppler ultrasound examination is the best predictor of late pregnancy outcome in systemic lupus erythematosus and/or the antiphospholipid syndrome. Rheumatology (Oxford) 2006;45 (03):332-338

69 Bates SM, Middeldorp S, Rodger M, James AH, Greer I. Guidance for the treatment and prevention of obstetric-associated venous thromboembolism. J Thromb Thrombolysis 2016;41(01):92-128

70 DGGG DGfGuGeV. Diagnostik und Therapie von Frauen mit wiederholten Spontanaborten (AWMF online). Available at: https://wwwawmforg/leitlinien/detail/11/015-050html

71 Bramham K, Thomas M, Nelson-Piercy C, Khamashta M, Hunt BJ. First-trimester low-dose prednisolone in refractory antiphospholipid antibody-related pregnancy loss. Blood 2011;117(25):6948-6951

72 Andreoli L, Bertsias GK, Agmon-Levin N, et al. EULAR recommendations for women's health and the management of family planning, assisted reproduction, pregnancy and menopause in patients with systemic lupus erythematosus and/or antiphospholipid syndrome. Ann Rheum Dis 2017;76(03):476-485

73 Tektonidou MG, Andreoli L, Limper M, Tincani A, Ward MM. Management of thrombotic and obstetric antiphospholipid syndrome: a systematic literature review informing the EULAR recommendations for the management of antiphospholipid syndrome in adults. RMD Open 2019;5(01):e000924

74 Ahmed A, Singh J, Khan Y, Seshan SV, Girardi G. A new mouse model to explore therapies for preeclampsia. PLoS One 2010;5(10):e13663

75 Lefkou E, Mamopoulos A, Dagklis T, Vosnakis C, Rousso D, Girardi G. Pravastatin improves pregnancy outcomes in obstetric antiphospholipid syndrome refractory to antithrombotic therapy. J Clin Invest 2016;126(08):2933-2940

76 Fanouriakis A, Kostopoulou M, Alunno A, et al. 2019 update of the EULAR recommendations for the management of systemic lupus erythematosus. Ann Rheum Dis 2019;78(06):736-745

77 Sciascia S, Hunt BJ, Talavera-Garcia E, Lliso G, Khamashta MA, Cuadrado MJ. The impact of hydroxychloroquine treatment on pregnancy outcome in women with antiphospholipid antibodies. Am J Obstet Gynecol 2016;214(02):273.e1-273.e8

78 Mekinian A, Lazzaroni MG, Kuzenko A, et al; SNFMI and the European Forum on Antiphospholipid Antibodies. The efficacy of hydroxychloroquine for obstetrical outcome in anti-phospholipid syndrome: data from a European multicenter retrospective study. Autoimmun Rev 2015;14(06):498-502

79 Lazzaroni MG, Fredi M, Andreoli L, et al. Triple antiphospholipid (aPL) antibodies positivity is associated with pregnancy 
complications in aPL carriers: a multicenter study on 62 pregnancies. Front Immunol 2019;10:1948

80 Sciascia S, Branch DW, Levy RA, et al. The efficacy of hydroxychloroquine in altering pregnancy outcome in women with antiphospholipid antibodies. Evidence and clinical judgment. Thromb Haemost 2016;115(02):285-290

81 Smyth A, Oliveira GH, Lahr BD, Bailey KR, Norby SM, Garovic VD. A systematic review and meta-analysis of pregnancy outcomes in patients with systemic lupus erythematosus and lupus nephritis. Clin J Am Soc Nephrol 2010;5(11):2060-2068

82 Antovic A, Sennström M, Bremme K, Svenungsson E. Obstetric antiphospholipid syndrome. Lupus Sci Med 2018;5(01):e000197

83 Clowse ME, Magder LS, Witter F, Petri M. Early risk factors for pregnancy loss in lupus. Obstet Gynecol 2006;107(2, Pt 1): 293-299

84 Mankee A, Petri M, Magder LS. Lupus anticoagulant, disease activity and low complement in the first trimester are predictive of pregnancy loss. Lupus Sci Med 2015;2(01):e000095

85 Andreoli L, Gerardi MC, Fernandes M, et al. Disease activity assessment of rheumatic diseases during pregnancy: a comprehensive review of indices used in clinical studies. Autoimmun Rev 2019;18(02):164-176

86 Meroni PL. Prevention \& treatment of obstetrical complications in APS: is hydroxychloroquine the Holy Grail we are looking for? J Autoimmun 2016;75:1-5

87 Yelnik CM, Lambert M, Drumez E, et al. Bleeding complications and antithrombotic treatment in 264 pregnancies in antiphospholipid syndrome. Lupus 2018;27(10):1679-1686
88 Arnaud L, Mathian A, Devilliers H, et al. Patient-level analysis of five international cohorts further confirms the efficacy of aspirin for the primary prevention of thrombosis in patients with antiphospholipid antibodies. Autoimmun Rev 2015;14(03): 192-200

89 Fanouriakis A, Kostopoulou M, Alunno A et al. 2019 update of the EULAR recommendations for the management of systemic lupus erythematosus. Ann Rheum Dis 2019;78(06):736-745. doi: 10.1136/annrheumdis-2019-215089. Epub 2019 Mar 29

90 Motta M, Chirico G, Rebaioli CB, et al. Anticardiolipin and antibeta2 glycoprotein I antibodies in infants born to mothers with antiphospholipid antibody-positive autoimmune disease: a follow-up study. Am J Perinatol 2006;23(04):247-251

91 Peixoto MV, de Carvalho JF, Rodrigues CE. Clinical, laboratory, and therapeutic analyses of 21 patients with neonatal thrombosis and antiphospholipid antibodies: a literature review. J Immunol Res 2014;2014:672603

92 Nalli C, Iodice A, Andreoli L, et al. Long-term neurodevelopmental outcome of children born to prospectively followed pregnancies of women with systemic lupus erythematosus and/or antiphospholipid syndrome. Lupus 2017;26(05):552-558

93 Groot N, de Graeff N, Avcin T, et al. European evidence-based recommendations for diagnosis and treatment of paediatric antiphospholipid syndrome: the SHARE initiative. Ann Rheum Dis 2017;76(10):1637-1641

94 Schreiber K, Sciascia S, de Groot PG et al. Antiphospholipid syndrome. Nat Rev Dis Primers 2018;(4):18005; Doi: 10.1038/ nrdp.2017.103 